\title{
磁気軸受におけるロータ・アキシャル方向への 不釣り合い振動補償器の適用の試み*
}

\author{
齋 藤 大 史 ${ }^{* *}$ 涌 井 伸 二***
}

Trial of Applying Unbalance Vibration Compensator to Axial Position of the Rotor with Active Magnetic Bearings

Daishi SAITO and Shinji WAKUI

\begin{abstract}
In industry, Turbo molecular pump (TMP) is utilized to make highly vacuum in the chamber. The rotor supported by the active magnetic bearings (AMB) in TMP vibrates caused by the unbalance of the mass of the rotor. This vibration is transmitted to casing of TMP and gives harmful influence on the device attached to TMP. As methods to suppress this vibration, Peak-of-Gain Control (JIS B 0913-1, Unbalance Force Counteracting Control: UFCC), Automatic Balancing System (JIS B 0913-1, Unbalance Force Rejection Control: UFRC) and Phase-Variable Control (PVC) have been reported. However, these methods have been applied to only radial direction of the rotor even though vibration with same cycle as unbalance vibration occurs in axial direction of the rotor. Additionally, conventional unbalance vibration compensator can not be applied to the three axes bearing which supports the rotor by AMB in only axial direction. Accordingly, in this paper, unbalance vibration compensators for axial direction are proposed. Through experiments, the proposed compensators are applied to the axial direction and exhibit effect of suppression of unbalance vibration.
\end{abstract}

Key words: turbo molecular pump, magnetic bearing, unbalance vibration, peak-of-gain control, automatic balancing system

\section{1. 緒言}

能動形磁気軸受 (Active Magnetic Bearing : 以下, AMB) は電 磁石に電流を通電することにより吸引力を発生させ, ロータを 非接触で支持する. そのため, 機械軸受に比べ摩擦損失がなく, オイル・メンテナンスフリーで半永久的に使用できるメリット がある ${ }^{1)}$

AMBはターボ分子ポンプ (Turbo Molecular Pump:以下, TMP) に広く利用されている ${ }^{2)}$. この TMP のロータを回転させる際, 不釣り合い振動が発生する. 同振動は幾何中心と慣性中心が異 なるロータを回転させることにより発生する ${ }^{3)}$.この振動はケー シングに伝達し, TMPが取り付けられた機器の振動環境に悪影 響を与える. そこで, 不釣り合い振動の補償として, 適応制御 法 ${ }^{4)}$ やッチフィルタを用いた手法 ${ }^{5)}$ が報告されている. また Peak-of Gain Control（JIS 規格では Unbalance Force Counteracting Control : UFCC を以下, PGC と略記), Auto-Balancing System (JIS 規格では Unbalance Force Rejection Control : UFRCを以下, ABS と略記), そして Phase-Variable Control (以下, PVC と略記) の トラッキングフィルタを用いた補償法が報告されている ${ }^{67)}$. 同 フィルタを用いた補償法はラジアル方向の不釣り合い振動を抑 制する. 一方, ロータのアキシャル方向にも回転周波数成分を もつ振動が発生している. これをアキシャル方向の不釣り合い 振動と呼ぶ. 本稿では, この振動を抑制する. 具体的な応用は 3 軸磁気軸受を想定している. 産業界ではラジアル方向に永久磁 石を用い,アキシャル方向に対してのみ $\mathrm{AMB}$ を用いる磁気軸受 も広く用いられているが, 従来のラジアル方向に対する不釣り

\footnotetext{
* 原稿受付 平成 29 年 6 月 2 日

掍载決定 平成 29 年 9 月 20 日

“学生会員 東京農工大学大学院工学府 (東京都小金井市中町 2-24-16)

… 正会員 東京農工大学大学院工学研究院
}

合い振動補償器はそのままでは適用することはできない.この 振動を抑制する一手法として動吸振器がある ${ }^{8)}$. しかし, これは TMP を取り付ける機器が変わるごとにパラメータ調整を要する. よって TMP それ自体の振動を抑制する必要がある.

本稿では所有の 5 軸能動形磁気軸受におけるロータのアキシ ヤル方向に専用の不釣り合い振動補償器を適用する. この補償 器はアキシャル方向にのみ能動的制御が施される 3 軸磁気軸受 にも適用できる. 本稿の構成は以下のとおりである. 2 章では 5 軸能動形磁気軸受の構造と従来のラジアル方向に対する不釣り 合い振動補償器について説明する. 3 章ではアキシャル方向に対 する不釣り合い振動補償器を提案する. 4 章ではこの補傊器を実 機に適用した結果を示す. 最後に 5 章で結論を述べる.

\section{5 軸能動形磁気軸受とラジアル方向に対する 不釣り合い振動補償器}

実験で用いる 5 軸能動形磁気軸受の構造と, 既知のトラッキ ングフィルタを用いた不釣り合い振動補償法を簡単に述べる.

\subsection{5 軸能動形磁気軸受}

図 1 に実験で用いる TMP の外钼, 図 2 に TMP 内部のロータ と 5 軸 $\mathrm{AMB}$ の構造, そして図 3 にその上面図を示す. 図 2 中央 に位置するロータはAMBによって, 支持されている. ブラシレ ス DC モータはロータを回転させる. $\left(x_{h}, y_{h}\right),\left(x_{b}, y_{b}\right)$ はそれぞれ， ラジアル方向の上部, 下部の位置信号を示す. また, $z$ はアキシ ヤル方向の位置信号を, $\theta$ はロータの回転角度を表す. サンプリ ング周波数 $10 \mathrm{kHz}$ の Digital Signal Processor（以下, DSP) をコ ントローラとして用いる.

図 4 に 5 軸 $\mathrm{AMB}$ の制御系を示す. ラジアル方向では, モー ド抽出により回転, 並進モードに分離された信号をそれぞれ PI 補償，PD 補償，位相進み補償を行い，さらにモード分配により 駆動指令を出力している. アキシャル方向には, ロータを安定 
浮上させるために, 擬似積分器, 位相進み補償器, そして PD 補 償器を適用した. 従来, ラジアル方向に図 4 の破線部で井んだ 不釣り合い振動補償器が適用される. 本稿では新たに同補償器 をアキシャル方向用に改良した. これを図 4 の太線部で井んだ 部分に適用し，不釣り合い振動を抑制する.

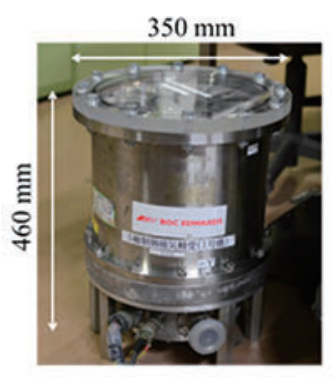

Fig.1 Overview of TMP

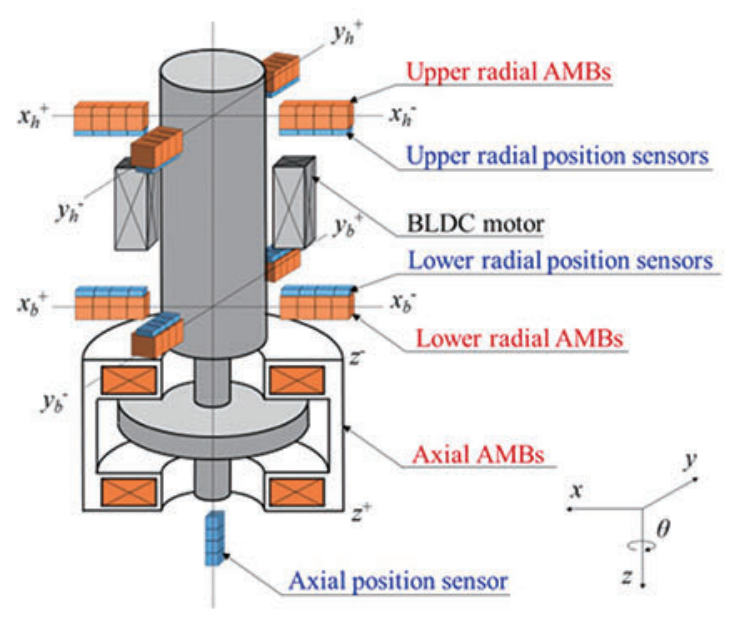

Fig.2 Structure and coordinate system of five-axes AMB in TMP

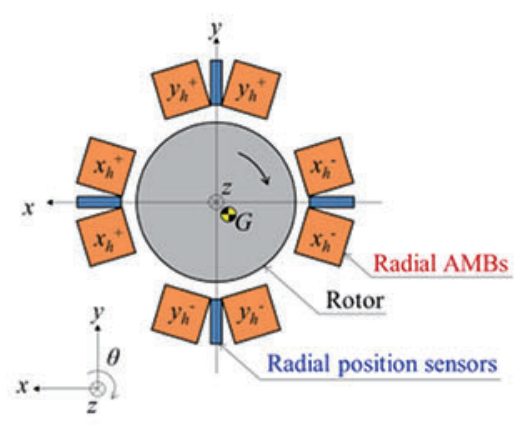

Fig.3 Top view of rotor and AMB system

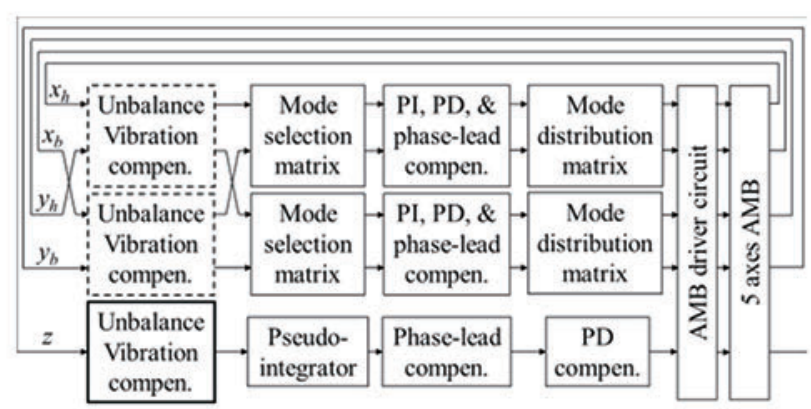

Fig.4 Block diagram of five-axes AMB and controller with axial unbalance vibration compensator

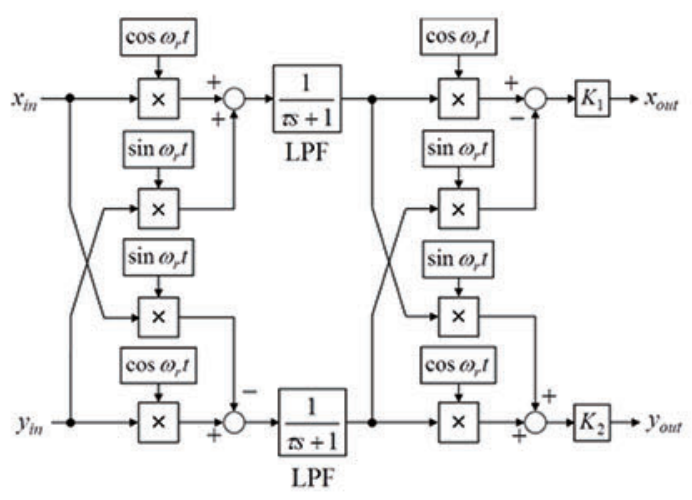

Fig.5 Block diagram of tracking filter

Table 1 Parameters of tracking filter

\begin{tabular}{l|l|l}
\hline Parameters & Unit & Description \\
\hline$x_{\text {in }}, y_{\text {in }}$ & $\mathrm{V}$ & Input position signals \\
\hline$x_{\text {out }}, y_{\text {out }}$ & $\mathrm{V}$ & Output signals \\
\hline$\omega_{r}$ & $\mathrm{rad} / \mathrm{s}$ & Rotational angular velocity \\
\hline$\tau$ & $\mathrm{s}$ & Time constant of LPF \\
\hline
\end{tabular}

\section{2 ラジアル方向に対する不釣り合い振動補償器}

回転時には周期的な外力が墈くことによりロータが振れ回る. これが不釣り合い振動を招く. 同振動は回転周波数に同期する. ロータの定格回転時とそれに至るまでの過渡状態においても不 釣り合い振動は発生するため, これを抑制するには回転周波数 に追従するトラッキングフィルタを用いた補償法が有効になる.

図 5 に同フィルタのブロック線図を示寸. 同図で使用した各 記号を表 1 にまとめた. トラッキングフィルタは狭帯域バンド パス型であり, 中心周波数は回転周波数に同期する. 詳細は文 献 7）を参照されたい. なお, 同フィルタを用いたPGC, ABS, そして PVCによる補償法は 3.2 節において後述する.

\section{3. アキシャル方向に対する 不釣り合い振動補償器}

従来のトラッキングフィルタを用いた不釣り合い振動補償法 をアキシャル方向に適用する方法と, 同方向における PGC, ABS, そして PVC の各特徴を述べる. 次に PGC が内部モデル原理に 基づいた外乱抑制手法であることを示寸. これを踏まえ, 高調 波振動を抑制する PGC を導出する. 最後に, ロータのアキシャ ル方向に発生する非整数次の $1 / 3$ 次分数調波を抑制する PGC を 導出する.

\subsection{2 軸トラッキングフィルタの変換}

ラジアル方向に対するトラッキングフィルタは $x, y$ 方向の 2 入力 2 出力系である. 一方, アキシャル方向に対する同フィル 夕は $z$ 方向の 1 入力 1 出力にする必要がある. そこで図 6 に示 すように, 従来の 2 入力 2 出力の干涉系であるトラッキングフ イルタを図形的に太線部分の信号の経路をたどることにより，1 入力 1 出力のフィルタとした. なお, 特許 3072994 号9)において, このフィルタと等価な 1 入力 1 出力のものがトラッキングフィ ルタの原理として説明される. しかし, 式展開のみでブロック 線図による具体的なフィルタの構造は示されていない. さらに 提案するフィルタは文献 10) のノッチフィルタとほぼ同一の構 造をもつ. 提案するフィルタは内部にローパスフィルタをもつ. 一方, 文献 10）のノッチフィルタはこのローパスフィルタが積 分器に置き換わっている. ただし, 同文献ではこのノッチフィ 
ルタを $x, y$ 方向それぞれに独立に適用している. つまり, 本稿 で提案するアキシャル方向への適用ではない. 図 6 の太線で示 寸信号の経路を具体的に書き直したのが図 7 である.

この 1 軸トラッキングフィルタの伝達関数 $G_{U T F}(s)$ を導出する. 図 7 中の $z_{L P F 1}(s)$ と $z_{L P F 2}(s)$ はオイラーの公式とラプラス変換によ り式(1)になる.

$$
\begin{aligned}
& z_{L P F 1}(s)=\frac{1}{2(\tau+1)}\left\{z_{i n}\left(s-j \omega_{r}\right)+z_{i n}\left(s+j \omega_{r}\right)\right\} \\
& z_{L P F 2}(s)=-\frac{1}{2(\tau s+1)}\left\{z\left(s-j \omega_{r}\right)-z_{\text {in }}\left(s+j \omega_{r}\right)\right\}
\end{aligned}
$$

また, $z_{\text {our }}(s)$ はオイラーの公式とラプラス変換により式(2)にな る.

$$
\begin{aligned}
z_{\text {out }}(s) & =\frac{1}{2}\left\{z_{L P F 1}\left(s-j \omega_{r}\right)+z_{L P F 1}\left(s+j \omega_{r}\right)\right\} \\
& -\frac{1}{j 2}\left\{z_{L P F 2}\left(s-j \omega_{r}\right)-z_{L P F 2}\left(s+j \omega_{r}\right)\right\}
\end{aligned}
$$

式(2)に(1)を代入することで, $G_{U T F}(s)$ を得る.

$$
G_{U T F}(s)=\frac{z_{\text {out }}(s)}{z_{\text {in }}(s)}=\frac{\frac{1}{\tau} s+\frac{1}{\tau^{2}}}{s^{2}+\frac{2}{\tau} s+\omega_{r}{ }^{2}+\frac{1}{\tau^{2}}}
$$

式(3)のボード線図を図 8 に示す.ここではロータの回転数は

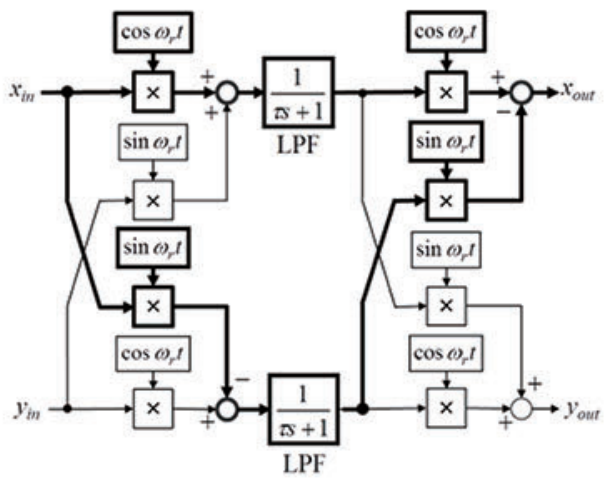

Fig.6 Modified block diagram of tracking filter

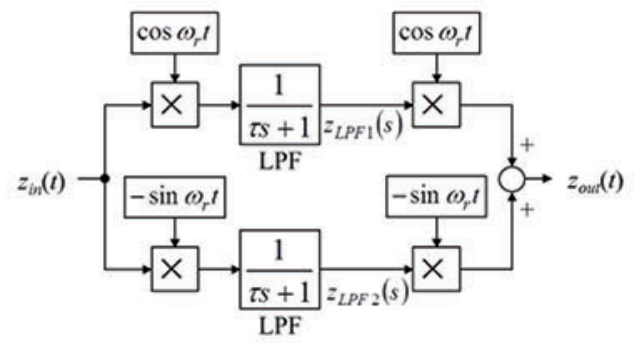

Fig.7 Block diagram of uniaxial tracking filter

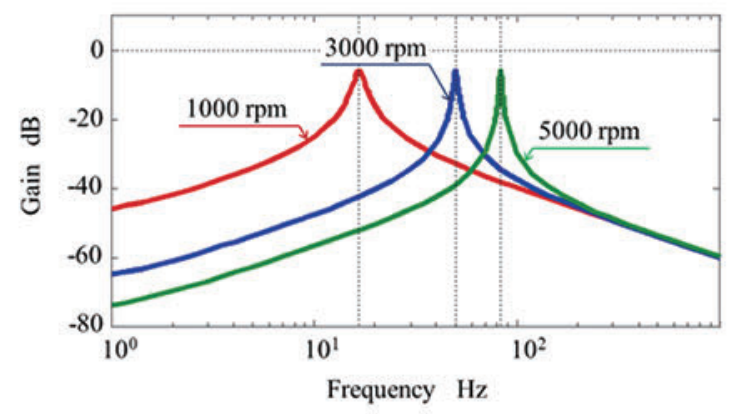

Fig.8 Bode plots of uniaxial tracking filter
1000，3000，5000 rpm である. 同図より，1 軸トラッキングフ イルタは回転周波数を中心周波数とした狭带域バンドパス型で ある.よって, ラジアル方向の同フィルタと同様の周波数特性 をもつ .

3.21 軸トラッキングフィルタ使用の不釣り合い振動補償器

1 軸トラッキングフィルタを用いた PGC, ABS, そして PVC が，ラジアル方向に適用されるそれらの周波数特性と同一であ ることを確認する.

(A) PGC : PGC は回転周波数における軸受剛性を大きくし，ロー 夕の振動を積極的に抑制する.PGC のブロック線図を図 9 に示 す. 同図では, 1 軸トラッキングフィルタ内のローパスフィルタ 前後で位相差を設けてある. これにより PGC 後段に別途, 位相 進み補償器を適用寸る必要がないといわれている ${ }^{9}$.これ以外は 位相差を設けない PGC の特徵と変わらない.この PGC の伝達 関数 $G_{U P G C}(s)$ は次式になる.

$$
\begin{aligned}
& G_{U P G C}(s)=1+K_{P G C} G_{U T F 1}(s) \\
& =\frac{s^{2}+\left(\frac{2+K_{P G C} \cos \varphi_{P G C}}{\tau}\right) s+\left(\omega_{r}^{2}+\frac{1+K_{P G C}\left(\cos \varphi_{P G C}-\omega_{r} \tau \sin \varphi_{P G \partial}\right)}{\tau^{2}}\right)}{s^{2}+\left(\frac{2}{\tau}\right) s+\left(\omega_{r}{ }^{2}+\frac{1}{\tau^{2}}\right)}
\end{aligned}
$$

ここで, $K_{P G C}$ はPGC のゲインである. 式(4)のボード線図を図 10 に示す. ロータの回転数は $3000 \mathrm{rpm}$ である. ここでは, トラ ッキングフィルタ内の位相差 $\varphi_{P G C}$ を $0,30,60 \mathrm{deg}$ とした. 同 図より回転周波数を中心周波数とする逆ノッチフィルタである. また， $\varphi_{P G C}$ の指定を大きくすると回転周波数における位相がよ り進む.

(B) ABS : ABS は回転周波数における軸受剛性を小さくすること

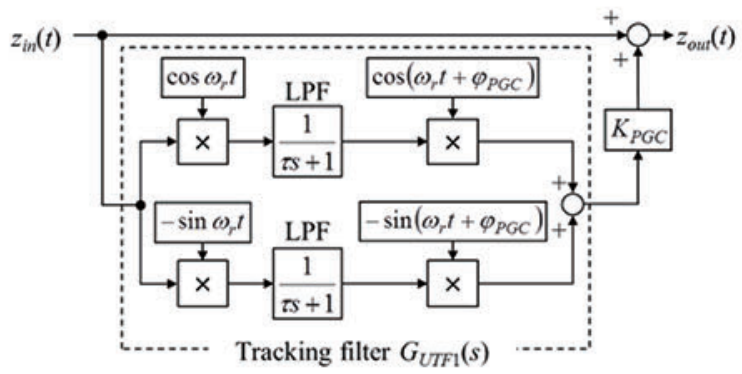

Fig.9 Block diagram of uniaxial PGC
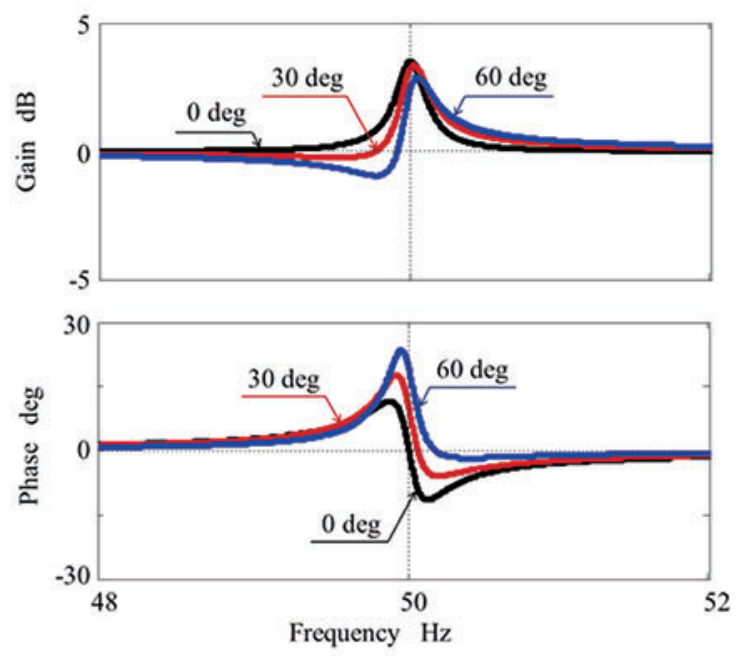

Fig.10 Bode plots of uniaxial PGC 


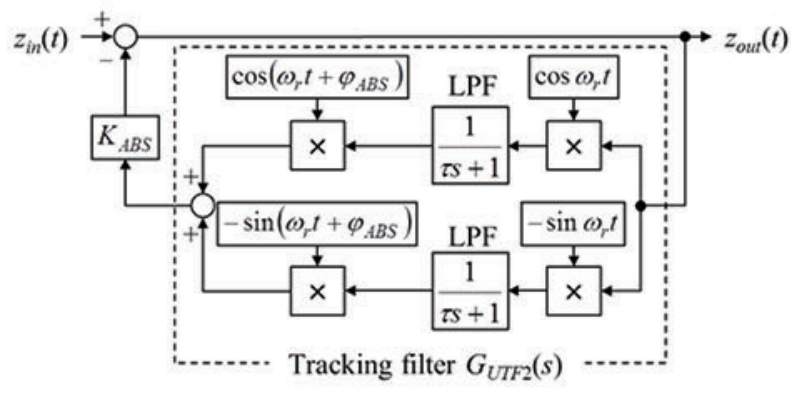

Fig.11 Block diagram of uniaxial ABS
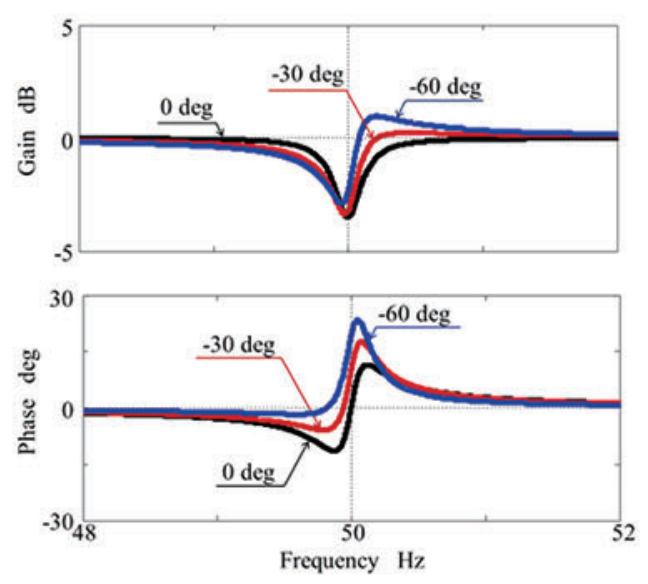

Fig.12 Bode plots of uniaxial ABS

で，ロータを慣性主軸まわりに回転させて振動を抑制する. 図 11 に ABS のブロック線図を示す. PGC が 1 軸トラッキングフ イルタをフィードフォワードで接続する. 一方, ABS はフィー ドバックで接続する. この伝達関数 $G_{U A B S}(s)$ は次式である.

$$
\begin{aligned}
& G_{U A B S}(s)=\frac{1}{1+K_{A B S} G_{U T F 2}(s)} \\
& =\frac{s^{2}+\left(\frac{2}{\tau}\right) s+\left(\omega_{r}^{2}+\frac{1}{\tau^{2}}\right)}{s^{2}+\left(\frac{2+K_{A B S} \cos \varphi_{A B S}}{\tau}\right) s+\left(\omega_{r}^{2}+\frac{1+K_{A B S}\left(\cos \varphi_{A B S}-\omega_{r} \tau \sin \varphi_{A B S}\right)}{\tau^{2}}\right)}
\end{aligned}
$$

ここで, $K_{A B S}$ は ABS のゲインである. 式(5)のボード線図を図 12 に示す. ロータの回転数は $3000 \mathrm{rpm}$ である. ここではトラッ キングフィルタ内の位相差 $\varphi_{A B S}$ を $0,-30,-60 \mathrm{deg}$ とした. 同図 より, 回転周波数におけるゲインを小さくするノッチフィルタ になる. また, $\varphi_{A B S}$ をマイナス方向に大きくすると, 回転周波数 における位相がより進む.

(C) PVC : ラジアル方向に対する PGC と ABS は周知の補償法で ある. 一方, PVC は筆者の一人ほかが提案したものである.こ れは軸受剛性を変化させることなく, 回転周波数における位相 を進めることでロータに減衰を与え, 振動を抑制する. PGC と ABS が軸受剛性を変化させるゲイン安定化手法とすれば, PVC は位相安定化手法に相当する ${ }^{7}$. 図 13 にアキシャル方向に適用 する PVC のブロック線図を示す. トラッキングフィルタ内に位 相差を設けた位相可変型 PGC と ABS を直列接続している.こ の伝達関数 $G_{U P V C}(s)$ は次式である.

$$
\begin{aligned}
G_{U P V C}(s) & =\frac{1+K_{P G C} G_{U T F 1}(s)}{1+K_{A B S} G_{U T F 2}(s)} \\
& =\frac{s^{2}+a_{1} s+a_{0}}{s^{2}+b_{1} s+b_{0}}
\end{aligned}
$$

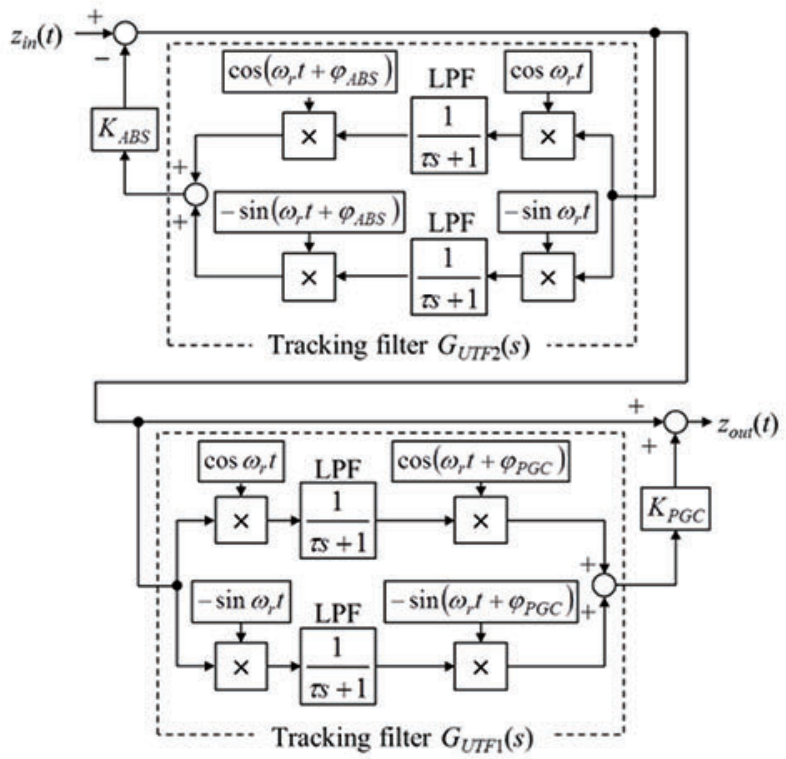

Fig.13 Block diagram of uniaxial PVC
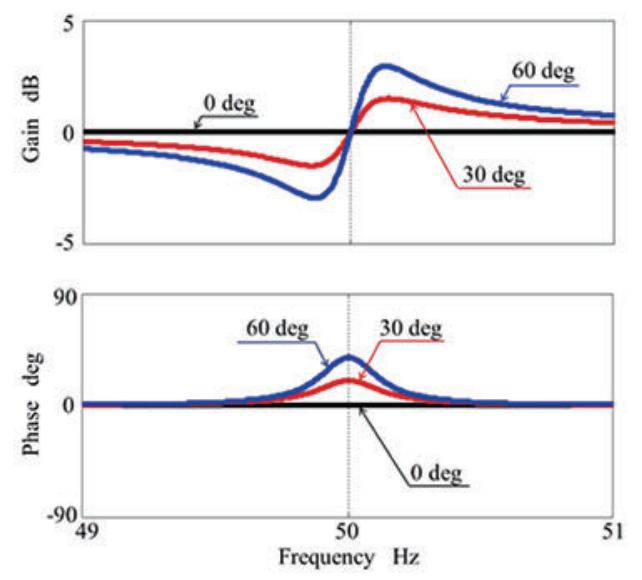

Fig.14 Bode plots of uniaxial PVC

$$
\text { ただし, } \begin{aligned}
a_{1} & =\frac{\left(2+K_{P G C} \cos \varphi_{P G C}\right)}{\tau}, \\
a_{0} & =\omega_{r}^{2}+\frac{1+K_{P G C}\left(\cos \varphi_{P G C}-\omega_{r} \tau \sin \varphi_{P G C}\right)}{\tau^{2}}, \\
b_{1} & =\frac{\left(2+K_{A B S} \cos \varphi_{A B S}\right)}{\tau}, \\
b_{0} & =\omega_{r}^{2}+\frac{1+K_{A B S}\left(\cos \varphi_{A B S}-\omega_{r} \tau \sin \varphi_{A B S}\right)}{\tau^{2}}
\end{aligned}
$$

式(6)のボード線図を図 14 に示す. ロータの回転数は $3000 \mathrm{rpm}$ である. このとき, PVC 内における PGC と ABS のゲインとト ラッキングフィルタ内の位相差はそれぞれ, $K_{P G C}=K_{A B S}=1.0$ と $\varphi_{P G C}=-\varphi_{A B S}=0,30,60 \mathrm{deg}$ である. このとき. 回転角周波数にお けるゲインは変化しない. 一方, $\varphi_{P G C}\left(=-\varphi_{A B S}\right)$ の指定を大きく するとより位相が進む.

\section{3 内部モデル原理に基づく高調波の抑制}

PGC は, 内部モデル原理に基づく外乱抑制方法と解釈されて いる ${ }^{11)}$.このことを応用し, 先行研究においてラジアル方向に 発生する不釣り合い振動の整数倍の周波数成分をもつ高調波振 動を抑制した ${ }^{11)}$.ここでは, この PGC を Harmonic-type PGC (以 下, HPGC) と呼ぶ. アキシャル方向に発生する高調波振動につ いてもラジアル方向と同様の抑制効果が期待できる. よって, アキシャル方向に対する HPGC の導出過程を示す. 
まず, 繰り返し制御器 ${ }^{12)}$ の極配置を踏まえて, 同制御器が内 部モデル原理に基づく外乱抑制手法であることを述べる. この ブロック線図を図 15 に示す．伝達関数 $G_{R C}(s)$ は次式となる.

$$
G_{R C}(s)=\frac{1}{1-e^{-L s}}
$$

$L$ は外乱周期である. 外乱角周波数 $\omega_{0}$ は $L$ を用いて表すと, $\omega_{0}=(2 \pi) / L$ となるので, 繰り返し制御器の極は式(7)より次式とな る.

$$
s= \pm j \frac{2 n \pi}{L}= \pm j n \omega_{0}(n=0,1,2, \ldots)
$$

式(8)より, 繰り返し制御器は外乱に相当する生成モデルを極 にもつ. 同制御器を閉ループ内に適用することにより, 外乱に よる定常応答の偏差を零にする.

次に, アキシャル方向に適用する PGC が繰り返し制御器と同 様に, 内部モデル原理に基づく外乱抑制法であることを説明す る. PGC の伝達関数は式(4)に示したとおりである. これより, PGC $の$ 極は

$$
s=-\frac{1}{\tau} \pm j \omega_{r}
$$

となる. $1 / \tau$ は実用上, ロータの回転角周波数の変動をカバーす るため, $\omega_{r}$ に比べ非常に小さく設定する. よって, PGCの極は $s= \pm j \omega_{r}$ と近似でき, ロータの回転周波数成分の外乱モデル, つ まり, 不釣り合い振動のモデルを生成する. よって, PGC は繰 り返し制御器と同様に, 内部モデル原理に基づく外乱抑制手法 といえる.

先行研究では, 繰返し制御器が外乱の整数倍の振動を抑制す ることと, PGC が同制御器と同様に内部モデル原理に基づいた 外乱抑制法であることから, ラジアル方向における不釣り合い 振動の 2 次高調波振動を抑制する HPGC を導出している. そこ で, ラジアル方向と同様にアキシャル方向の同振動を抑制する HPGC を導出する. このブロック線図を図 16 に示す. 同図中の $K_{H P G C}$ は HPGC のゲインである. HPGC 正弦波, 余弦波のブロ ックは回転角周波数 $\omega_{r}$ の 2 倍に設定している. このとき HPGC の極は $s=-(1 / \tau) \pm j 2 \omega_{r}$ となる. $1 / \tau$ は既述のとおり， $\omega_{r}$ に比べ非常 に小さい. よって, $s= \pm j 2 \omega_{r}$ と近似される. 同制御器は 2 次高調 波振動成分の生成モデルとなるために, 同成分に対する振動抑 制効果をもつ.

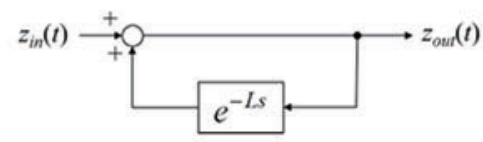

Fig.15 Block diagram of repetitive controller

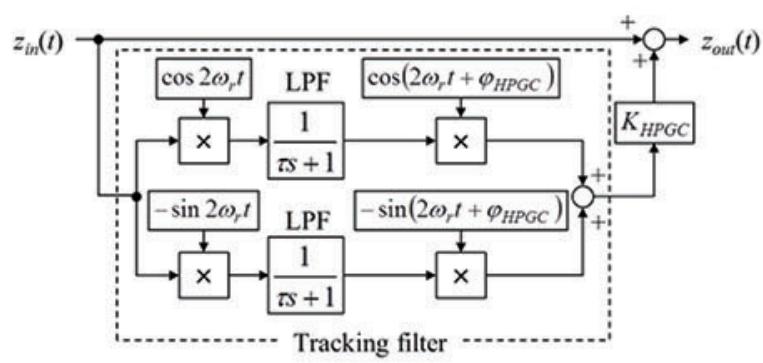

Fig.16 Block diagram of uniaxial HPGC

\section{$3.41 / 3$ 次分数調波の抑制}

ロータの回転時に発生するアキシャル方向の $1 / 3$ 次分数調波 振動を抑制する. 図 17 にアキシャル方向の振動のパワースペク トルを示寸. 回転数は $1000 \mathrm{rpm}$ である. 不釣り合い振動にあた る $16.6 \mathrm{~Hz}$ 成分に加え, その $1 / 3$ 倍の周波数成分の $5.55 \mathrm{~Hz}$ 付近 の振動が大きい. 文献 13) ではラジアル方向において, この $1 / 3$ 次分数調波振動が発生することを確認している. 一方，所有の TMP において同振動はラジアル方向には現れず, アキシャル方 向に確認された. 同振動が発生する要因として, 軸受の非線形 性にあることが知られている ${ }^{14)}$. 繰り返し制御器は基本波の整 数倍成分に対応寸るもので, 分数調波成分は抑制対象ではない. しかし, 内部モデル原理にしたがえば，分数調波成分も抑制で きるはずである. よって, 分数調波振動を抑制する Subharmonic type PGC（以下, SPGC) を導出する.

SPGC のブロック線図を図 18 に示す. 同図中の $K_{S P G C}$ は SPGC のゲインである. 分数調波振動と同一のモデルを SPGC の極に もたせるために, 回転角周波数 $1 / 3 \omega_{r}$ の正弦および余弦波を生成 する必要がある. ここで, 図 16 に示す HPGC は正弦波と余弦波 のブロックに 2 倍の回転角周波数を代入することで高調波成分 をもつ正弦および余弦波を生成した. 一方, SPGC は $1 / 3$ 倍の回 転角周波数を代入しても分数調波成分をもつ正弦および余弦波 は生成されない. 図 18 では, 機能を理解しやすいように $1 / 3$ 倍 の回転角周波数を代入しているが, 実際は別途に $1 / 3$ 次分数調波 用の正弦および余弦波の生成器が必要になる. この説明のため に図 19 に TMP から出力されるパルスと DSP で生成される正弦 波を示す. 同図(a)のパルスはロータが 1 回転するごとに立ち下 がる. これをDSP 上で処理することにより回転角周波数 $\omega_{r}$ をも つ正弦および余弦波を得る. また，パルスが立ち下がると, こ れ以前の正弦波の生成は止まり，この時点におけるロータの回 転角周波数に基づく正弦波を生成しはじめる.つまり，パルス の立ち下がり時は正弦波の值が初期值の零をとる. 同図(b)の PGC は生成される正弦波が 1 周期経過した時点で初期値に戻る. また，同図(c)で示すように HPGC は固有角周波数が PGC の 2 倍であるため, 2 周期経過した時点で初期值に戻る. 一方, 同図

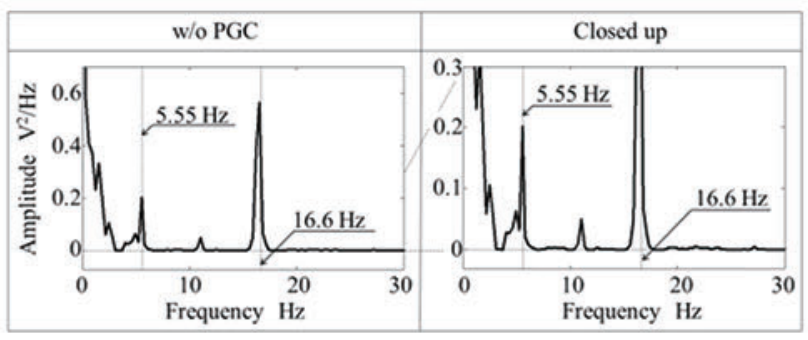

Fig.17 Power spectrum of axial position

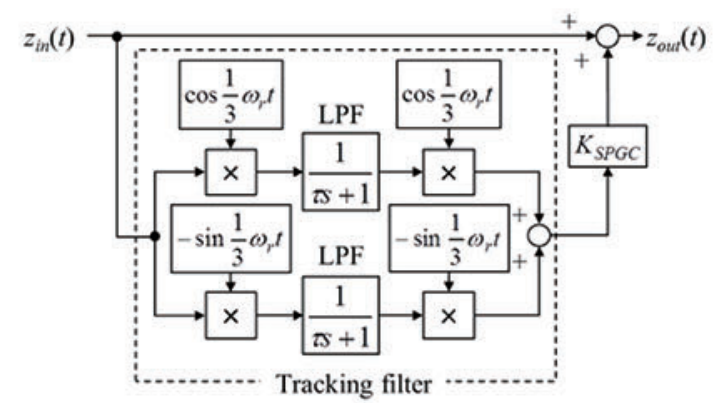

Fig.18 Block diagram of uniaxial SPGC 


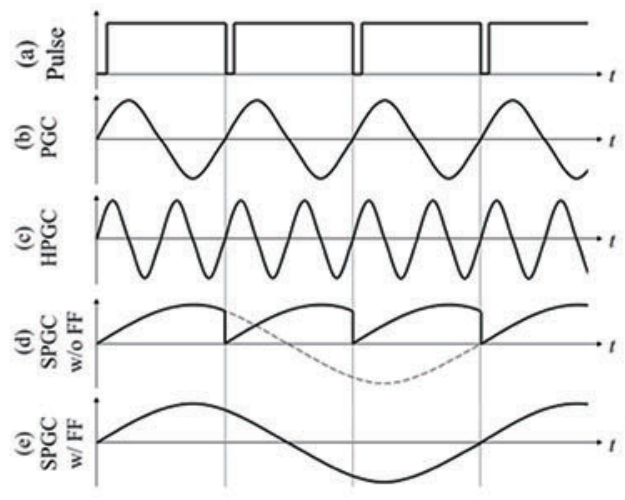

Fig.19 Pulse and sine waves of unbalance vibration compensator

(d)の固有角周波数が PGC の $1 / 3$ 倍の SPGC は $1 / 3$ 周期経過した 時点で,パルスの立ち下がりにより初期値に戻る.よって, HPGC と同樣の手法では 1 周期分の波形を得られない. そこでパルス の後段にフリップフロップ回路を用いた 3 進カウンタを適用す る.これにより,図 19(a)に示すパルスが3 回立ち下がったとき, 1 回立ち下がる. よって, 同図(e)に示すように SPGC の正弦波 は1周期経過した時点で初期値に戻り, 同周期分の波形を得る.

\section{4. 回 転 実 験}

実機にアキシャル方向の不釣り合い振動補償器を適用する. まず， 3.2 節で述べた PGC，ABS，そしてPVCを用い，不釣り 合い振動の基本波振動を抑制する. 次に HPGC を用い, ロータ の定常振動に発生する不釣り合い振動の 2 次高調波振動を抑制 する. また SPGC を適用し，アキシャル方向にのみ確認される $1 / 3$ 次分数調波振動を抑制する. 最後に, 5 軸能動形磁気軸受人 の応用として, 従来のラジアル方向に対する不釣り合い振動補 償器とアキシャル方向の同補償器を同時に適用し, さらなる抑 制効果を示寸.

\section{1 不釣り合い振動の基本波成分抑制}

3.2 節で述べた PGC, ABS, そして PVC を実機に適用し，ア キシャル方向に発生するロータの不釣り合い振動の基本波振動 を抑制する.

(A) PGC の適用 : PGC を適用した際のアキシャル方向における ロータの時間応答と，これに対するパワースペクトルを図 $20 に$ 示す. 回転数は低回転の $1000 \mathrm{rpm}$ である. PGC のゲイン $K_{P G C}$ は $0.5,1.0,1.5$ とし, トラッキングフィルタ内の位相差は零で ある. 同図左側の時刻 $0 \mathrm{~s}$ から 2 秒間を PGC 適用前の定常振動, そして, 時刻 $3.0 \mathrm{~s}$ で PGCによる制御に切り替えて 1 秒間の過渡 現象を除外した時刻 4.0 から $6.0 \mathrm{~s}$ までを $\mathrm{PGC}$ 適用後の定常振動 としてパワースペクトルを求めた. 同図左側より, PGC を適用 すると, ロータの振動が抑制される. この振動成分は同図右側 より, 回転周波数成分の不釣り合い振動といえる. よって, ア キシャル方向の PGC は同方向の振動抑制に効果がある. なお, アキシャル方向におけるロータの位置にオフセットが存在する. この理由は図 4 に示すようにラジアル方向とアキシャル方向と もに, 完全積分器が実装されていないためである. これは通常, 磁気軸受を用いるとき， ロータが固定子と接触しないことのみ を要求されるためである.

(B) $\mathrm{ABS}$ : ABS を適用した際のアキシャル方向におけるロータの 時間応答を図 21 左側に, そして ABS の適用前と適用後の各定 常振動に対するパワースペクトルを図 21 右側に示す. ABS は口

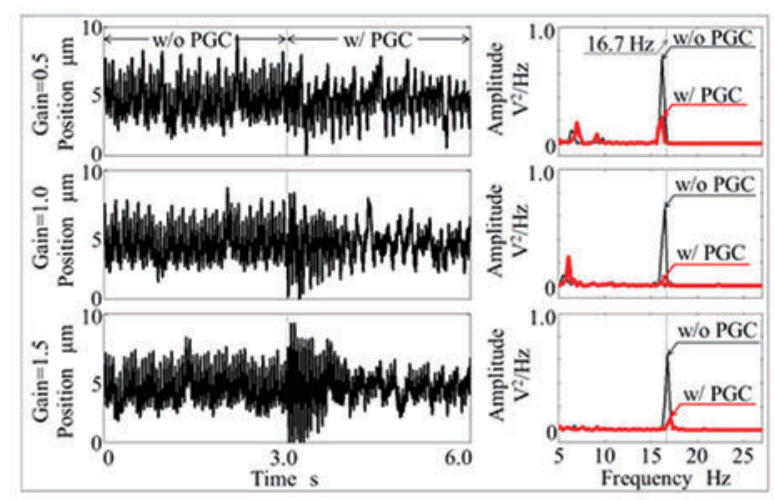

Fig.20 Time responses and power spectrums of axial position with uniaxial PGC (1000 rpm)

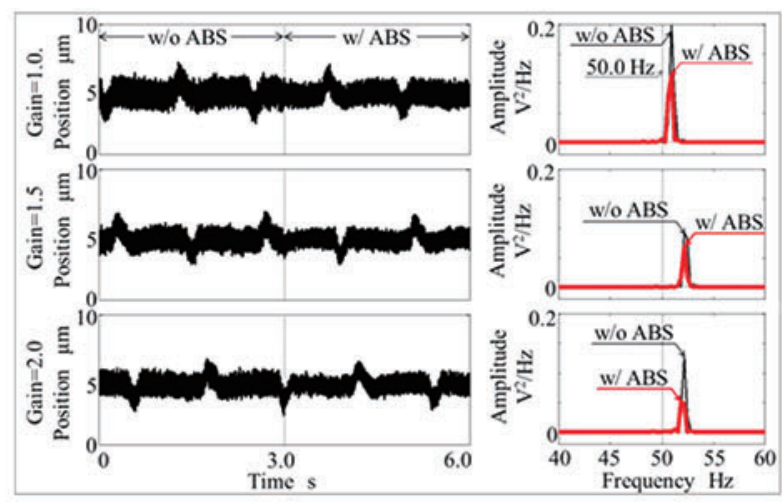

Fig.21 Time responses and power spectrums of axial position with uniaxial ABS (3000 rpm)

ータの閉ループ応答の带域周波数外で適用される. よって, 回 転周波数を $3000 \mathrm{rpm}$ にして実験を行った. ABS のゲイン $K_{A B S}$ は 1.0, 1.5, 2.0 とし, トラッキングフィルタ内の位相差は零で ある. パワースペクトルは(A)と同様に求めた. 同図左側より, ABS を適用寸る場合, 振動の振幅が小さくなる. また, 同図右 側より回転周波数 $50 \mathrm{~Hz}$ の不釣り合い振動成分が $\mathrm{ABS}$ を適用す ることで減少している. よって, アキシャル方向の ABS は同方 向の不釣り合い振動の抑制効果をもつ.

(C) PVC : 回転数が $1000 \mathrm{rpm}$ における PVC の振動抑制効果を説 明する. PVC を適用した際のアキシャル方向におけるロータの 時間応答を図 22 左側に示す. このとき PVC のゲインは $K_{P G C}=$ $K_{A B S}=1.0$ とし, トラッキングフィルタ内の位相差は $\varphi_{P G C}=-\varphi_{A B S}=60$, 90，120 deg である. 位相差が零の PVC を適用すると振動は抑 制されない. 一方, 位相差を与えると抑制される. 位相差が大 きくなると, 振動の抑制効果も大きくなる. なお, $60 \mathrm{deg}$ より 大きくなると抑制量に変化が見られなくなった. 図 22 左側の時 間応答に対するパワースペクトルを同図右側に示す. パワース ペクトルの求め方は(A)と同様である. 図 22 右側より, 位相を 進めた PVC を適用すると回転周波数成分の不釣り合い振動が抑 制される. よって, PVC はアキシャル方向の同振動の抑制効果 をもつ. 次に, 回転数が $3000 \mathrm{rpm}$ の際の抑制効果を説明する. 図 22 と同様に, PVCを適用した際の振動の時間応答と, この振 動のパワースペクトルを図 23 に示す. 同図左側より，位相差を 設けた PVC を適用すると振動の振幅が小さくなる. 同図右側よ り, 抑制された振動成分は回転周波数の $50 \mathrm{~Hz}$ である. よって, PVCにより不釣り合い振動が抑制された. 


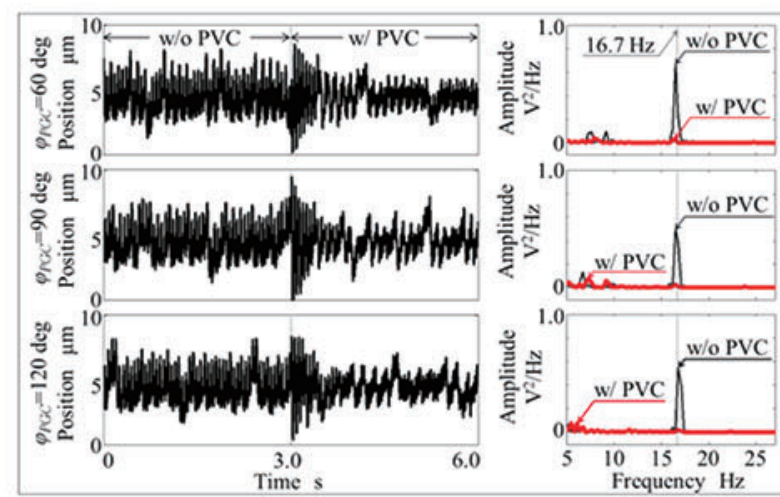

Fig.22 Time responses and power spectrums of axial position with uniaxial PVC (1000 rpm)

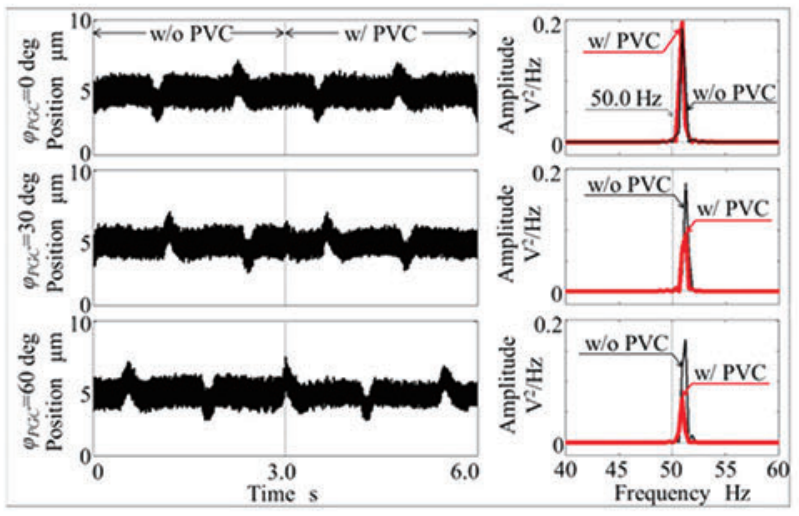

Fig.23 Time responses and power spectrums of axial position with uniaxial PVC (3000 rpm)

\section{2 高調波と分数調波振動の抑制}

HPGC を適用し，アキシャル方向に発生する不釣り合い振動 の 2 次高調波振動を抑制する. HPGC を適用した際のロータの 振動の時間応答と, これに対するパワースペクトルを図 24 に示 す.ここでは, 回転数は $1000 \mathrm{rpm}, \mathrm{HPGC}$ のゲイン $K_{H P G C}$ は 1.0 , そしてトラッキングフィルタ内の位相差 $\varphi_{H P G C}$ は $0,30,60 \mathrm{deg}$ である. 同図では高調波振動の変化を明瞭にするために, あら かじめ PGC を適用し，不釣り合い振動の基本波振動を抑制して ある. 同図左側上段より HPGC のトラッキングフィルタ内の位 相差を零としたとき, 振動振幅が大きくなる. この成分は同図 右側上段より 2 次高調波である. 悪化の理由は制御器の演算処 理と DSP の入出力の際の A-D 変換, D-A 変換, センサ, そして パワーアンプの位相遅れにより HPGC がロータの高調波成分に 負の減衰を与えたことである. これらの位相遅れを補償するた めに，トラッキングフィルタ内に位相差を設けた HPGC を適用 した結果が同図中段と下段である. 位相差が零のときに比べ, $30 \mathrm{deg}$ のときは振動が悪化しない. さらに位相差を大きくした $60 \mathrm{deg}$ のとき, 高調波振動が抑制される. したがって, 繰り返 し制御と同様に基本周波数の整数倍に対応する周期信号を生成 する HPGC は不釣り合い振動をさらに抑制する.

次に, SPGCを用いて $1 / 3$ 次分数調波を抑制する. SPGC を適 用した際のロータの位置信号の時間応答を図 25 左側に, そして, この時間応答に対するパワースペクトルを同図右側に示す．こ こでは，回転数は $1000 \mathrm{rpm}, S P G C$ のゲイン $K_{S P G C}$ は $1.0,2.0$, 4.0 である. 同図では高調波振動の抑制のときと同様, 分数調波 振動の変化を明瞭にするために，あらかじめ不釣り合い振動の

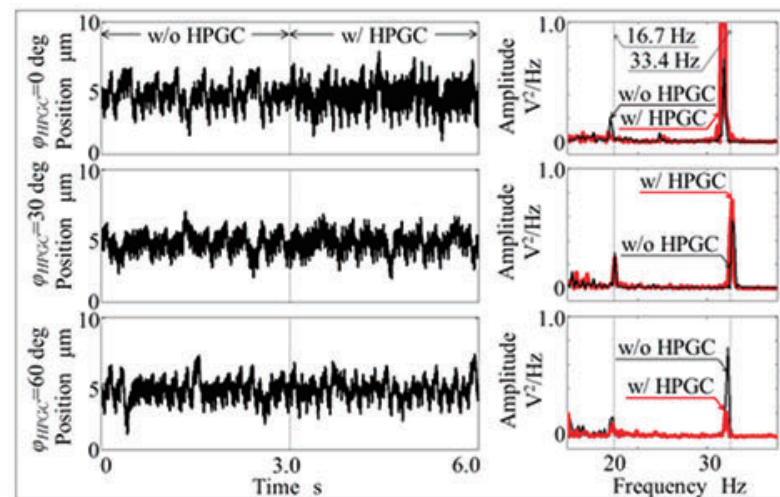

Fig.24 Time responses and power spectrums of axial position with uniaxial HPGC (1000 rpm)

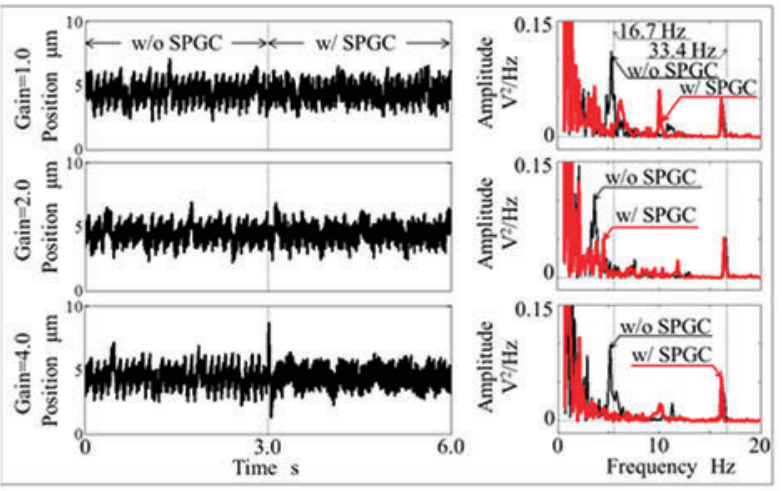

Fig.25 Time responses and power spectrums of axial position with uniaxial SPGC (1000 rpm)

基本波振動を抑制してある. 同図左側より SPGC を適用すると 振動が抑制された.この振動は同図右側より $1 / 3$ 次分数調波成分 である. よって, 内部モデル原理に基づく補償器を適用すると, 不釣り合い振動の高調波に限らず，分数調波についても抑制で きる.

\section{3 ラジアルおよびアキシャル方向への不釣り合い振動補 償器の同時適用}

5 軸能動形磁気軸受への応用として, 従来のラジアル方向に対 する不釣り合い振動補償器に加えて, アキシャル方向の同補償 器を適用する. アキシャル方向の振動をさらに抑制することで, この補償器の有用性を示寸. 図 26 上段に不釣り合い振動補償を しない場合, 中段にラジアル方向に同補償器を適用した場合, そして下段にラジアルおよびアキシャル方向に同補償器を適用 した場合のロータのアキシャル方向における定常振動を示す. ここでは回転数は $1000 \mathrm{rpm}$, ラジアル方向の不釣り合い振動補 償器はゲイン $K_{P G C}=2.0$ の PGC, そしてアキシャル方向の同補侻 器はゲイン $K_{H P G C}=1.0$ でトラッキングフィルタ内の位相差 $\varphi_{H P G C}=60 \mathrm{deg}$ の 2 次高調波振動を抑制する HPGC である．同図 より, ラジアル方向の PGC を適用するとアキシャル方向の振動 が抑制される.ここでアキシャル方向に HPGC を追加すると, さらに振動が抑制される. 図 27 に各定常振動のパワースペクト ルを示す．同図よりラジアル方向の PGC を適用すると, ラジア ル方向に加えアキシャル方向の不釣り合い振動の基本波振動が 抑制される. しかし， 2 次高調波振動は残存する. この振動はラ ジアル方向では基本波振動に比べ, 非常に小さい. よって, ラ ジアル方向の HPGC を適用してもアキシャル方向の同振動は抑 制できない. ラジアル方向の PGC とアキシャル方向の HPGC を 


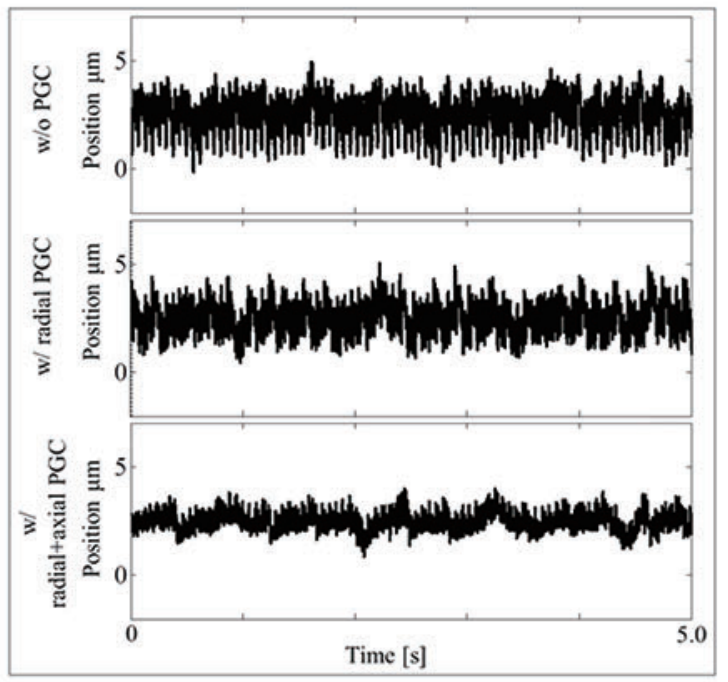

Fig.26 Time responses of axial position without and with PGCs (1000 rpm)

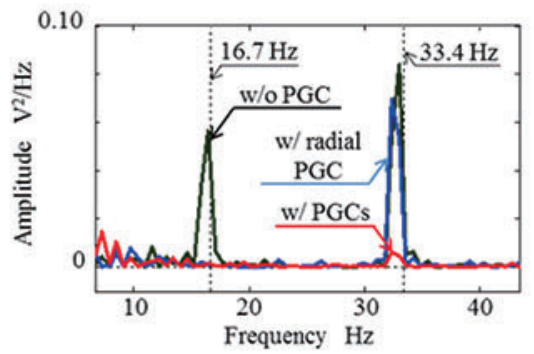

Fig.27 Power spectrums of axial position without and with PGCs (1000 rpm)

適用すると, 基本波に加え 2 次高調波振動が抑制される. 結果 より, 5 軸磁気軸受において, ラジアル方向に加えアキシャル方 向の不釣り合い振動補償器を適用すると, さらなる振動抑制効 果が得られる. なお, 所有のターボ分子ポンプではラジアル方 向に不釣り合い振動補償を施したとき, 同方向に加え, アキシ ヤル方向の振動が抑制される. 一方, アキシャル方向の同補僋 を適用してもラジアル方向の振動に変化はない.

\section{5. 結言}

本稿の結論は以下のとおりである.

(1) 能動形磁気軸受において周知の不釣り合い振動補償は半 径方向に施される. 本稿では同補償をアキシャル方向には じめて適用した.

(2) 従来の 2 入力 2 出力系のロータのラジアル方向に対するト ラッキングフィルタを用いた不釣り合い振動補償器をブ ロック線図から信号の経路をたどることにより，1 入力 1 出力のアキシャル方向に適用する同補傥器を導出した. ま
た 5 軸能動形磁気軸受のアキシャル方向に同補償器を適用 した.

(3) ラジアル方向の PGC が内部モデル原理に基づく外乱抑制 手法であることが既に報告されている.このことを踏まえ, 本稿で導出したアキシャル方向の PGC も同原理に基づく 抑制手法であることを示した. これを応用し，不釣り合い 振動の高次波と分数調波成分を抑制する HPGC と SPGC を 導出した.

(4) 5 軸能動形磁気軸受において, 従来のラジアル方向の PGC とアキシャル方向の高次振動を抑制する HPGC を同時に 適用した.

(5) アキシャル方向の不釣り合い振動補償により, 同方向の不 釣り合い振動の抑制効果を得た. さらに, アキシャル方向 における不釣り合い振動の高次波振動と分数調波振動を それぞれ HPGC と SPGC を用いることにより抑制した. また, 従来のラジアル方向の不釣り合い振動補償器とアキ シャル方向の同補償器を同時に適用することにより, アキ シャル方向の振動がラジアル方向における単独の補償に 比べさらに抑制された. これらをもって, アキシャル方向 の不釣り合い振動補傥器の有用性を示した.

\section{参 考 文 献}

1) 進士忠彦: 磁父軸受の現状と高精度化, 精密工学会誌, 67, 7 (2001), 1086 .

2) 上山拓知 : ターボ分子ポンプ用磁気軸受の最近の開発動向, ターボ 機械, 32, 7(2004), 432.

3) R. ガッシュ, H. ピュッツナー: 回転体の力学, 森北出版, (2004), 4

4) Liu, Zi-he, Kenzo Nonami, and Yuichi Ariga: Adaptive unbalanced vibration control of magnetic bearing systems with rotational synchronizing and asynchronizing harmonic disturbance, JSME International Journal Series C Mechanical Systems, Machine Elements and Manufacturing, 45, 1 (2002) 142.

5) Herzog, R., Buhler, P., Gahler, C., and Larsonneur, R: Unbalance compensation using generalized notch filters in the multivariable feedback of magnetic bearings, IEEE Transactions on control systems technology, 4, 5 (1996) 580.

6) H. Habermann, M. Brunet, and P. Joly: Device for damping the critical frequencies of a rotor suspended by a radial electromagnetic bearing, United States Patent 4128795(1978).

7) 中村泰貴, 涌井伸二: 5 軸能動形磁気(軸受の不釣り合い振動補償器 に対する一設計法, 日本機械学会踚文集, 81，824(2015).

8) 日本雪子 : 除振機構, 特開 2012-032004(2012)

9) 高木亭之, 松下修已, 平井洋武: トラッキングフィルタ付制御回路, 特開 2-246510(1990).

10) Zheng, S., Chen, Q., and Ren, H.: Active balancing control of AMB-rotor systems using a phase-shift notch filter connected in parallel mode, IEEE Transactions on Industrial Electronics, 63, 6 (2016) 3777.

11) 中村泰贵, 涌井伸二 : 5 軸能動形磁父軸受における不釣り合い振動 補頱群の関係性とそれを活用した振動抑制, 日本機械学会踚文集, 82, 837 (2016) 15-00607.

12) 原辰次, 綝返し制御 : 計測と制御, 25, 12 (1986) 1111.

13) 稲垣瑞穂: 高速回転体の非線形振動解析, 豊田中央研究所 R\&D レ ビュー, 30, 1 (1995) 1 .

14) 高橋直彦, 三浦治雄, 福岛康雄 : 高速夕ーボ圧縮機用磁父軸受制御 系の設計と試剙結果, 日本機械学会論文集 C 編, 72, 721 (2006) 2912. 